Linguistik Terapan 14 (2) (2017): 172-181

Jurnal Linguistik Terapan Pascasarjana

Available online

http://jurnal.unimed.ac.id/2017/index.php/JLT-Unimed

\title{
POLITENESS STRATEGY USED BY THE ANTAGONIST AND THE PROTAGONIST CHARACTERS IN "THE SILENCE OF THE LAMBS" (A PRAGMATICS STUDY)
}

\section{TITIK ISWATI}

Sri Minda Murni

I Wayan Dirgeyasa

Diterima Agustus 2017; Disetujui Oktober2017; Dipublikasikan Desember 2017

\begin{abstract}
This research dealt with politeness strategy used in the movie The Silence of the Lamb. The aims of this study were (1) to investigate the kinds of politeness strategies used by the antagonist and protagonist characters when they expressed their utterances in the film "The Silence of the Lambs", (2) to explain how the strategies used by the two characters, (3) to know the reasons of those characters in employing politeness strategies. The research was conducted by using qualitative design. The source of data of this study was the movie. The data were collected through documentary technique and the instrument was the documentary sheet. The findings of this study revealed that: (1) Based on the categories of politeness strategies proposed by Brown and Levinson, all categories of politeness strategies were found in this film. (2) The bald on record strategy was used for eight times by the antagonist, while the protagonist used it for five times. (3) The use of politeness strategy by the antagonist and protagonist was aimed to perform acts based on J. R. Searle's theory, namely representatives, directives, commissives and declaration. In addition, new strategies were found in this study. They were self-image building, provoking and influencing.
\end{abstract}

Keywords: Politeness Strategy, Antagonist, Protagonist, Pragmatics

How to Cite: Iswati, Titik (2017).

Politeness Strategy Used by the Antagonist and the Protagonist Characters in "The Silence of the Lambs". (A Pragmatics Study). Jurnal Linguistik Terapan Pascasarjana Unimed, 14 
(2):172-181.

ISSN 2407-7410

\section{INTRODUCTION}

Communication has an important role in our life. According to Gartside (1986:1) communication is the art of sharing anything. In its vital sense, it means a sharingof ideas and feelings in a mood mutual understanding. We adapt our conversation to different situations. For example, wecan easily say something that would be seen discourteous among strangers or among our friends and we avoid over formally with our friends. In both situations above,we try to avoid making the hearer embarrassed and uncomfortable.

Story has been the foundation of rituals that empower both individual and collective values since society began. Story provides both identity and standards to live by and is thus essential to our well being. It serves as a mirror reflecting who we are and what we believe in. It is soul which gives meaning to both life and art.

Normally in a real life, polite language is generally used by good people and impolite language is used by bad people. This phenomenon also happens in movies stories. Movie is the reflection of life. Some of the scenes in the movie represent the reality of life. The conversations between the characters in the film are the portrait of the real daily people conversations. People can learn many beneficial things by watching movie since it is one of many other ways to transfer the knowledge.

Sadistic, cruel or brutal characters in movies occasionally employ rude and impolite words or expressions. This phenomenon did not occur in the film "The Silence of the Lambs". The psychopathic killer, Dr. Lecter, performed polite words and expressions. The examples of his utterances were as the following:

DR. LECTER: “Closer, please... Clo-ser...”

CLARICE STARLING:(Clarice does not answer but she follows Dr. Lecter instruction)

In this scene, Dr. Lecter wanted to see the officer's credentials and she held it up for his inspection. Although the antagonist, Dr. Lecter, had used politeness strategy, namelybald on record, but his utterance did not seem to be polite to the hearer's perspective. She showed her fear when she talkd to him.

In another example, Dr. Lecter instructed Clarice to sit in the chair in front him. He talked slowly behinds his bars but Clarice seemed to be very afraid although he spoke slowly to her. He usedbald on record strategy.

DR. LECTER: "Mmmmm... That's rather slippery of you Officer Starling. Sit. Please”.

CLARICE STARLING: (Clarice replies nothing but she follows the instruction). 
The dialog in another scene was described as the officer, Clarice Starling, rolled him the questionnaires, in his sliding food tray. Dr. Lecter rose, glanced at it, turned a page or two disdainfully. He usednegative politeness strategy called minimize the imposition by using the word "little" in his utterance.

DR. LECTER: "Oh, Officer Starling... do you think you can dissect me with this blunt little tool?" CLARICESTARLING: "No. I only hoped that your knowledge".

Although Dr. Lecter employed some politeness strategy in his utterances, he was not really polite anyhow. He expressed somethingpolitely but ironically the hearer felt uncomfortable when she talked to him. In pragmatics, the utterances of the antagonist contained impoliteness although he expressed the utterances politely.

People generally behave in accordance with their expectation concerning their public self-image or face wants to be respected. Face means public self-image of a person; it refers to the emotional and social sense of self that everyone has and expects everyone to recognize (Yule, 1996:60). Face has two aspects, positive and negative.

An individual's positive face is reflected in his or her desires to be liked, approved of, respected of and appreciated by others. While an individual's negative face is reflected in the desire not be impeded or put upon, to have the freedom to act as one chooses (Thomas, 1995:169). Therefore, people in their relationship need to preserve both kinds of faces for themselves and the people they interact with the politeness utterances.

According to Brown and Levinson (1987:65), certain kinds of acts intrinsically threaten face, namely those acts that by their nature run contrary to the face want of the hearer and / or of the speaker. For example, the hearer'spositive face will damage when the speaker insulting the hearer, and also thehearer's negative face will damage when the speaker order the hearer. It alsocould damage the speaker's own positive and negative face for example, when the speaker admits that he has failed in his job and when the speaker offers help to thehearer. In order to avoid or minimize to reduce the possibility of damage to the hearer's face or tothe speaker's own face, he or she may adopt certain strategies.

Brown and Levinson sum up human politeness behavior in four strategiesamong them are the bald on record strategy, the positive politeness strategy, thenegative politeness strategy, and bald off record strategy. Furthermore, the research is aimed to analyze the politeness strategies basedon Brown and Levinson's politeness strategy in a film.

There are some international journals which gave the contribution to this study. First, the journal of Politeness Strategies in Email Exchanges in Persian written by Izadi and Zilaie (2012). This study aimed to report on the most frequent positive politeness strategies employed by a group of Iranian Persian 
speakers in their email compositions to their close and fairly close friends. The results indicated that positive politeness strategy "group identity markers" and "give gifts to $\mathrm{H}$ " were the most dominant strategies in the email exchanges. It is hoped that the results could foster ways for intercultural computer mediated communication by introducing the commonest politeness strategies in Persian email exchanges.

Another article is The Application of Politeness Strategies in English and Chinese Movie Reviews by $\mathrm{Mu}$ (2015). Under the framework of Brown and Levinson's politeness strategy theory, this research explored the differencesin the application of positive and negative politeness strategies in five English and five Chinese movie reviews.Both quantitative and qualitative differences were found. English reviewers used politeness strategies morefrequently than Chinese reviewers. Top five positive politeness strategies used by English and Chinese reviewersare the same. However, as for negative politeness strategies, there are slight differences between English andChinese reviews. English reviews use more questions, nominalizing, impersonalizing, minimizing the imposition, and being pessimistic. However, instead of impersonalize $S$ and $H$; Chinese reviews tend to state FTA as a general rule. Also, the order of top five negative politeness strategies is different between English andChinese reviews.

In addition, English reviews use more positive politeness strategies like notice, exaggerate and offer than Chinese reviews. Chinese reviews use more in-group identity markers, jokes, and give more reasons. Whencomes to negative politeness strategies, English reviewers try to minimize the imposition, impersonalize $S$ and $H$, and nominalize when writing. However, Chinese reviewers use more hedges, apologize more, and try to state the FTA as a general rule. Those differences may be caused by several possible reasons, including three main aspects: cultural differences,different educational style, and different language systems. The research would like to investigate the kinds of politeness strategies which wereused by the antagonist and protagonist characters when they expressedtheir utterances, to explain how the strategies were used by the two characters and to know the reasons of those characters in employing politeness strategies.

\section{RESEARCH METHODOLOGY}

This research belongs to a descriptive qualitative method. Bodgan and Taylor define qualitative research as a research that presents the descriptivedata in the form of written or oral words of people and behavior which can be observed as stated by Saldana, Miles and Huberman (1992). The data in this research were the antagonist and protagonist utterances in the movie. The source of data of the research was the script dialog of the film entitled "The Silence of the Lambs", which was downloaded from the link www.imsdb.com/scripts/Silence-of-the-Lambs.html. The object of the research was politeness strategy. 
In collecting the data, this research useddocumentary method. The document analysis method was simultaneous applied in such a way by observing carefully the entire data source that containedthe usage of politeness strategies by the antagonist and protagonist characters. The utterances were meticulously observed, identified, noted down and classified. The technique implemented to support document analysis method was note-taking.

The collecting data were scientifically analyzed in accordance with the theory applied which was preceded to the process of data analysis and the presentation of the analyzed data. These were the scientific steps to find out the answer to the research problems. The technique of data collection was the script downloading from the internet link. The instrument of data collection was used to get information based on the purpose of the research. The instrument was the recorder and the research instrument which was used in this study was documentary sheet.

\section{FINDINGS AND DISCUSSIONS}

\section{Findings}

There were four kinds of politeness strategies found in the movie. They were bald on record, positive politeness, negative politeness and bald off record strategies. Both of the characters dominantly employed the positive politeness strategy.

The antagonist character used all of the four strategies. From thirty-three utterances, he employed bald on record for eight times (24.2\%), positive politeness for twelve times (34.4\%), negative politeness for five times (15.2\%)and the last strategy used was off record for eight times (24.2\%).

The protagonist character also used all of the four strategies. From seventeen utterances, she employed bald on record for five times $(29.4 \%)$, positive politeness for seven times $(41.18 \%)$, negative politeness for once (5.9\%)and the last strategy used was off record for four times $(23.52 \%)$.

The employment of the politeness strategies by the antagonist was more frequent than the antagonist in their utterances. The example of it could be seen from the use of off record strategyby the protagonist that was twice as many as protagonist. It implied that the antagonist seemed to be more polite than the protagonist but this assumption was not actually right because the employment of politeness strategies by the antagonist was done for certain intended purposes. On the other hand, the protagonist employed politeness strategies for she really wanted to behave politely. There are four strategies in politeness and the usage of politeness strategy by different kinds of characters. The use of bald on record strategy by the two kinds of character. The antagonist used more strategy than the protagonist. He employed the strategy eight times while the protagonist only employed the same strategy for five times. In some scenes, the antagonist employed this strategy to convey his meaning in the most direct, clear, unambiguous and concise way. The example of this strategy was explained below (Data 13): 
DR. LECTER (DL): Do you know why he's called Buffalo Bill? Tell me. The won't say.

CLARICE (CL): I'll tell you if you'll look at this form.

$D L:$ (he considers, then nods)

CL: It started as a bad joke in Kansas City Homicide. They said... this one likes to skin his humps.

In this scene, the antagonist (Dr.Lecter) used Bald on record strategy. It was marked by the word "tell me", in which this word contained imperative meaning. The word "tell me" began with the base form of a verb. Here, Dr. Lecter wanted Clarice to answer him the reason why the most dangerous criminal, who was being investigated by the FBI, was called by Buffalo Bill. The antagonist character (Dr. Lecter) had known the reason so that the aim of his question to the protagonist character (Clarice) was only for testing her and showing his power that he was more superior than her in the investigated case. Meanwhile, the protagonist did not want to be inferior in front of the antagonist.It could be seen from her answer (I'll tell you if you'll look at this form). This answertold us that the bargaining position of the protagonist was the same as the antagonist. Her aim was to be able to solve the case by involving the antagonist's help.

Positive politeness is oriented toward positive face of the hearer. It is not only used by the participants who have known each other fairly well, but also used as a kind of metaphorical extension of intimacy to imply common ground or to sharing of wants to limited-extent between strangers. From fifteen (15) sub-strategies in positive politeness based on Brown and Levinson, it was found that there were five sub-strategies in positive politeness strategies which were employed by the antagonist, namely Intensify interest to the hearer, Use in-group identity markers, Presuppose/riselassert common ground, Give (or ask for) reasons, assume or assert reciprocity. On the other hand, the protagonist character employed three sub-strategies out of fifteen in positive politeness based on Brown and Levinson, namely Intensify interest to the hearer, Offer / promise, Include both the speaker and the hearer in the activity, Give (or ask for) reasons, and Assume or assert reciprocity.

The negative politeness strategy is oriented mainly toward satisfying hearer's face. This strategy is characterized by self-effacement, formality and restrain. There are ten sub-strategies in negative politeness based on Brown and Levinson and the antagonist character used two of those sub-strategies, namely Minimize the imposition and Give deference. The antagonist character employed the negative politeness strategy in reaching his goals. Meanwhile, the data showed that from ten sub-strategies in negative politeness, the protagonist employed only one sub-strategy namely Question/hedge. The examples of the use of the strategies by the antagonist were described as the following (Data 8):

CL: (shifting uncomfortably) Did you do those drawings, Doctor?

DL: Yes. That's the Duomo, seen from the Belvedere. Do you know Florence?

CL: All that detail, just from memory...? 


\section{DL: Memory, Officer Starling, is what I have instead of view}

Giving deference is sub-strategy number 5 in negative politeness. There are two ways in doing this strategy. First, the speaker humbles and abases himself. Second, the speaker raises the hearer. In this case, he used the second way. He addressed the protagonist by calling her with 'officer'. He treated her as superior by using such a kind of address form. Table 1 shows the kinds of politeness strategy.

Table 1. Kinds of Politeness Strategy Used by the Antagonist and Protagonist Characters

\begin{tabular}{llcccc}
\hline & & \multicolumn{3}{c}{ Kinds of Characters } \\
\cline { 3 - 6 } No & \multirow{2}{*}{ Types of Strategies } & \multicolumn{2}{c}{ Antagonist } & \multicolumn{2}{c}{ Protagonist } \\
\cline { 3 - 6 } & & \multicolumn{2}{c}{ Data } & \multicolumn{2}{c}{ Data } \\
\cline { 3 - 6 } & & Frequency & Percentage & Frequency & Percentage \\
\hline 1 & Bald on record & 8 & 24.2 & 5 & 29.4 \\
\hline 2 & Positive Politeness & 12 & 36.4 & 7 & 41.18 \\
\hline 3 & Negative Politeness & 5 & 15.2 & 1 & 5.9 \\
\hline 4 & Bald off record & 8 & 24.2 & 4 & 23.52 \\
\hline & Total & $\mathbf{3 3}$ & $\mathbf{1 0 0}$ & $\mathbf{1 7}$ & $\mathbf{1 0 0}$ \\
\hline
\end{tabular}

\section{Findings}

Based on the data analysis, the findings of this study were formulated as the following:

1. The antagonist employed more politeness strategies than the antagonist.

2. The employment of the four strategies by the antagonist was aimed to be dominant and superior towards others in which it could be seen from the antagonist mimes, expressions and tones when he spoke to the hearer.Based on the categories of politeness strategies proposed by Brown and Levinson, all categories of politeness strategies were found in The Silence of the Lamb.Thedominant category of politeness strategy used by the antagonist as well as protagonist was positive politeness strategy and from fifteen types of positive politeness strategy proposed by Brown and Levinson, in this study, the dominant strategy used by the antagonist was strategy 3 , intensify interest to hearer.

3. The use of politeness strategy by the antagonist and protagonist characters was aimed to perform acts based on J. R. Searle's theory, namely representatives, directives, commissives and declaration. Although they employed the same categorization of acts, the purposes of their acts were slightly different. The protagonist used politeness strategies for she really had an intention to behave 
politely. Meanwhile, the antagonist had certain aims in employing the strategies such as persuading, underestimating, dominating and threatening the hearers.

4. It was found new strategies that the employment of the politeness strategies by the antagonist was for self-image building, provoking and influencingthe hearers with his utterances.

\section{Discussion}

1. Based on the categories of politeness strategies proposed by Brown and Levinson, all categories of politeness are found in The Silence of the Lambsand the dominant category of politeness strategy which is used by the antagonist as well as protagonistispositive politeness strategy. From fifteen types of positive politeness strategy proposed by Brown and Levinson, in this study, the dominant strategy which is used by the antagonistis strategy 3 , intensify interest to hearer.

2. The employment of the four strategies by the antagonist is aimed to reach the acts in being dominant and superior towards others in which it can be seen from the antagonist mimes, expressions ad tones when he speaks to the hearer. After analyzing the data, it is found a new theory that the employment of the politeness strategies by the antagonist is for self-imagebuilding, provoking and influencingthe hearers with his utterances.

3. In general phenomenon, good people generally communicate with good or polite language. Since real life is reflected in movies, it usually also happens in movies. A good character or protagonist generally employs polite utterances while a bad character or antagonist rarely uses polite utterances. Sadistic, cruel or brutal characters in movies occasionally employ rude and impolite words or expressions, but different thing occurs in the film "The Silence of The Lambs" where the psychopathic killer, Dr. Lecter, performs polite words and expressions. The employment of polite expressions by the antagonist character in this film does not really mean polite anyway. It is done for being superior, intimidating, provoking, influencing, deceiving and threatening the hearers in which all of these phenomena can be seen from the antagonist mimes, facial expressions, and intonations when he speaks to the hearers.

4. The phenomena of this research results were slightly different from the theory of politeness. The antagonist character used more politeness strategies compared to the protagonist character. The employment of the strategies by the antagonist was intended to certain aims like to manipulate the situation, to be dominant towards others and to deceive the hearers. This was slightly different from the protagonist politeness strategies employment which was aimed to be polite.

\section{CONCLUSIONS}


Based on the data analysis, there are some valuable points that can be concluded, they are:

1. There were six factors affecting language shift and language maintenance occured in intermarriage chinese families namely bilingualism, migration, economic, environment, demographic, and attitude.

2. The language shift and language maintenance in intermarriage Chinese families occured since there are two languages exist in interethnic marriage couple. The existence of two languages means the competition between two languages. The competition of couple's languages in four intermarriage Chinese families led to language maintenance in three families namely Chinese Man - Batak Woman, Acehnese Man - Chinese Woman, Javanese Man - Chinese Woman and language shift occured in one family namely Chinese Man - Malaynese Woman.

3. The reasons why language shift and language maintenance occured in intermarriage Chinese families are bilingualism in which the man or woman mastered two languages which led to language maintenance, migration in which the women migrate to follow their husband which led to language shift and language maintenance, economic factor dealing with the men and women's occupations which affected them to maintain or to shift their languages, environment where they lived in homogenous or heterogenous ethnic affected them to maintain or to shift their language, demographic factor which made them to use Indonesian language, and attitude which might be postive to maintain language or negative to make language shift occured.

\section{SUGGESTIONS}

This study has investigated the politeness strategy used by the antagonist and protagonist character in a film.Based on the conclusions stated above, this study has some suggestions to the readers as provided in the following items:

1) Multimodal discourse analysis can be used to analyze multiple modes, like the modes in movies.

2) Further studies on politeness strategies in various movies genres such as horror, drama,action, fiction and science-fiction should be carried out because it is possible to find out other kinds of strategies and acts in movies.

\section{REFERENCES}

Brown, P. \& Levinson, S.C. 1987 [1978]. Politeness: Some Universals in Language Usage. Cambridge: Cambridge University Press. 
Izadi, Ahmad. 2012. Politeness Strategies in Email Exchanges in Persian.Journal of Comparative Literature and Culture (JCLC) 86 Vol. 2, No. 1

Levinson, S.C. 1985. Pragmatics. Cambridge: Cambridge University Press.

Miles, M.B., Huberman, A.M., Saldana, J., 2014. Qualitative Data Analysis.Sage Publication.

Perrine, Laurence., and Thomas R. Arp. 1988. Literature Structure, Sound, and Sense. Florida: Harcourt Brace Jovanovich Publisher.

Pickering, James H., and Jeffry D. Hoeper. 1962. Concise Companion to Literature. New Jersey: Prentice Hall.

Rahardi, Kunjana, 2005. Pragmatik: Kesantunan Imperatif Bahasa Indonesia. Jakarta: Erlangga.

Richard J. Watts. 2003. Politeness. Cambridge: Cambridge University Press.

Sell, D. Roger. 1992. Literary texts and diachronic aspects of politeness. In R. Watts, S. Ide, \& K.

Yule. George. 1996. Pragmatics. Hawaii: Oxford University Press. 